\section{Australian Journal of \\ Crop Science}

AJCS

ISSN:1835-2707

\title{
Productive characteristics of peanut cultivars fertilized with wood ash
}

\author{
Edna Maria Bonfim-Silva ${ }^{1}$, Pollyanna Yoko Takenaka ${ }^{1}$, Júlio José Nonato ${ }^{2}$, Salomão Lima Guimarães ${ }^{1}$, \\ Tonny José Araújo da Silva ${ }^{1}$
}

\author{
${ }^{1}$ Institute of Agricultural Sciences and Technology, Federal University of Mato Grosso, Rondonópolis, MT, 78736- \\ 900, Brazil \\ ${ }^{2}$ Faculty of Agronomy and Zootechnic, Federal University of Mato Grosso, Cuiabá, MT, 78060-900, Brazil
}

\author{
*Corresponding author: embonfim@hotmail.com
}

\section{Abstract}

Aiming to assist small farmers, the search for low cost fertilizers and soil acid correctives has intensified. The wood ash waste is an alternative, which can act as fertilizer and corrective. It is also from available materials, which are reuse-able with less environmental impact. The objective of this study was to evaluate the effect of wood ash doses $\left(0,6,12,18,24\right.$ and $\left.30 \mathrm{~g} \mathrm{dm}^{-3}\right)$ on the productive characteristics of peanut cV. IAC OL3 and IAC 503. The experiment was carried in a complete randomized block in factorial scheme $2 \times 6$ with five replications in a greenhouse at the Federal University of Mato Grosso campus of Rondonópolis, MT. The substrate was Cerrado Oxisol to fill $1.5 \mathrm{dm}^{3}$ pots. The analysis of variance with sequential polynomial regression test was employed. The results showed that incorporation of wood ash to the soil was beneficial to the productive characteristics of peanuts. The dry mass of pods was influenced by wood ash application with higher results found for cultivar IAC 503 . To the variables leaf dry mass, root dry mass, number of pods, grains pot ${ }^{-1}$ and grains yield showed no significant interaction between wood ash and cultivars. This study recommends wood ash doses in the range between $22.34 \mathrm{~g} \mathrm{dm}^{-3}$ and $29.78 \mathrm{~g} \mathrm{dm}^{-3}$.

Keywords: Arachis hypogaea L.; organic fertilizer; soil acidity corrector; solid waste; soil fertility.

Abbreviations: CEC_cation exchange capacity; O.M._organic matter; SB_base sum.

\section{Introduction}

Full vegetative and productive development of agricultural plants needs essential nutrients to be available in adequate quantities. Supply may occur with supplementation using organic or inorganic sources or both combinations.

Most fertilizers have synthetic origin (inorganic) and a high cost to purchase which minimizes the economic return to farmers especially for small ones. Because of this, the search for alternative and efficient sources is extremely important. The energy generated in industrial processes by burning wood has as waste called "wood ash" (Bonfim-Silva et al., 2017a). This waste may not be properly disposed and it can cause environmental pollution. Combining security in energy production with the need for low-cost fertilizers and soil acid corrective have risen the opportunity to reuse wood ash by incorporating it into the soil.

The physicochemical properties of ash may be different based on its source. Generally, they have high solubility and significant amounts of potassium (K), magnesium (Mg), calcium (Ca) and phosphorus (P) (Etitgni and Campbell, 1991; Osaki and Darolt, 1991; Eriksson, 1998). In addition the contain iron (Fe), manganese $(\mathrm{Mn})$, sodium $(\mathrm{Na})$, boron $(\mathrm{B})$, zinc $(\mathrm{Zn})$, copper $(\mathrm{Cu})$ and molybdenum $(\mathrm{Mo})$ in smaller quantities (Osaki and Darolt, 1991).

It also can acts as a soil acidity corrector (Osaki and Darolt, 1991; Saarsalmi et al., 2010; Bonfim-Silva et al., 2018) and in aluminum (Al) toxicity (Ferreira et al., 2012), a facts that can be attributed to the high concentration of calcium and magnesium oxides, hydrocarbons and hydroxides according to Haraldsen et al. (2011).

Previous studies have shown increments in plant growth by addition of wood ash to the soil, among which are barley (Cruz-Paredes et al., 2016), Brassica napus L. (Nabeela et al., 2016), cowpea (Awodun, 2007; Bonfim-Silva et al., 2017a), gerbera (Bär et al., 2018), gladiolus (Pereira et al., 2016) and safflower (Bonfim-Silva et al., 2018). However, there is lack of information for peanut production in Brazilian soil conditions.

Peanut (Arachis hypogaea L.) is an oleaginous species originating from South America (Silva et al., 2017) that occupies an estimated area of 28 million hectares being the fourth most cultivated oilseed worldwide (FAO, 2017).

Brazil is the second peanut producer and exporter in Latin America's ranked just behind Argentina (EMBRAPA, 2014; Gong et al., 2018) which average $25 \%$ of production are destined for exportation (ABICAB, 2018).

This is not much information on the agronomic management of peanut crop grown under wood ash as fertilizer. Because of this, the recommendations used by producers are based on technical bulletins for other regions and crops.

In order to test an alternative fertilizing with low-cost combined with peanut cultivars, this study aimed to evaluate the productive characteristics of peanut cultivars 
with high yield potential fertilized with wood ash doses cultivated in Cerrado Oxisol.

\section{Results and Discussion}

After the results of analysis of variance, there was significant interaction between the factors for dry mass of pods. For the others variables there were significant differences for some factors.

\section{Leaf and root dry mass}

The cultivar IAC 503 showed greater accumulation for leaf and root dry masses, when compared to the cultivar IAC OL3 (Table 1).

These cultivars have distinct growth cycles and the cultivar IAC OL3 has a shorter cycle compared to the cultivar IAC 503 (IAC, 2019). Commonly the longer cycle for vegetative growth cause a greater accumulation in plant matter.

Faster cycles imply reduction of productive potential, compared with crops that have longer cycles (Dall'Agnol, 2009).

The incorporation of wood ash $\left(29.78 \mathrm{~g} \mathrm{dm}^{-3}\right)$ into the soil influenced the leaf dry mass reaching to the highest accumulation of $15.79 \mathrm{~g}$ (Fig 1A). The root dry mass was adjusted to linear regression model with an increment of $41.81 \%$, when compared to the highest dose of the interval with the absence of wood ash fertilization (Fig 1B).

Dry matter accumulated in the peanut roots may have increased due to the direct influence of the high amount of calcium (Ca) supplied by wood ash as this nutrient is directly related to the plant cell elongation. Leyser (2018) and Dindas et al. (2018) proposed that the action of auxins hormone with $\mathrm{Ca}^{2+}$ results in less rigid cell wall, allowing the increase in cell volume inducing growth.

Increases in roots results in more area to absorb water and nutrients from soil, which can induce further shoot growth.

Amongst the nutrients that are readily available for absorption by the roots is phosphorus (P) which is found in considerable quantities in composition of wood ash used (Table 4).

Phosphorous is one of the elements that maximizes cell division and becomes indispensable for the growth of both shoots and roots (Obernberger et al., 2006; Cross-Wall et al., 2016; Cabral et al., 2018) even it can directly influence the amount of leaves when associated with other nutrients (Bonfim-Silva et al., 2017a).

The increase in dry mass with the use of organic fertilizers is already proved in other crops such as canola (Nabeela et al., 2015), cowpea (Bonfim-Silva et al., 2017a), jack beans (Bonfim-Silva, et al., 2017b) and gerbera (Bär et al., 2018).

\section{Number and dry mass of pods}

There was a significant difference in number of pods among cultivars. The IAC 503 cultivar reached the highest number of pods (Table 2).

The dose of $23.65 \mathrm{~g} \mathrm{dm}^{-3}$ of wood ash corresponded to an average of 26 pods per pot (Fig 2A).

For the dry mass of pods, interaction between the factors was observed after application of of $26.16 \mathrm{~g} \mathrm{dm}^{-3}$ wood ash in IAC OL3 cultivar and $22.99 \mathrm{~g} \mathrm{dm}^{-3}$ for the IAC 503 cultivar (Fig 2B).
The increase in the number of pods and the dry mass of pods may be related to the high amount of $\mathrm{Ca}$ in the ash composition (Table 4).

Among the nutrients, characteristics of $\mathrm{Ca}$ in plant physiology is the essentiality to maintain pollen tube formation and pollen grain sprouting, when associated with phytohormones (Gao et al., 2019), which will eventually form the pods and grains.

Apart from calcium, another element of such importance for the formation of reproductive structures is the nitrogen $(\mathrm{N})$. The supply of this nutrient to peanuts is possibly occurred in plant's association with native species of rhizobia in the soil, since there was not supply via mineral fertilizer and the amount of $\mathrm{Ca}$ in the wood ash treatments were too low (Table 4).

The growth of jack beans fertilized with wood ash suggested the same hypothesis of association with native nitrogen fixing bacteria due to the absence of $\mathrm{N}$-fertilizers (BonfimSilva et al., 2017b)

The $\mathrm{N}$ is an element directly related to yield of peanuts, which together with the magnesium forming the molecule of chlorophyll that is inherent to photosynthetic reactions (Marschner, 2012).

Considering that the association of legume roots with rhizobacterias is highly favored by the high increase in the concentration of soil available P, Bonfim-Silva et al. (2017b) explained that the enzyme responsible for $\mathrm{N}_{2}$ breakdown (nitrogenase) has a high energy cost that could be supplied with wood ash fertilization.

\section{Peanut grain yield}

The IAC 503 cultivar obtained higher number of grains per pot and higher grain yield, when compared to the IAC OL3 cultivar (Table 3).

The higher accumulation of dry matter from both shoots and roots (Table 1) was reflected in higher grain yield by the IAC 503 cultivar because during the growth stage there is the accumulation of reserves that later will be destined to the formation of productive characteristics and grains (Taiz et al., 2015).

The regression test adjustment indicated that the most efficient dose of wood ash to produce maximum number of grains pot $^{-1}$ is $22.34 \mathrm{~g} \mathrm{dm}^{-3}$, corresponding to 44 grains per pot (Fig $3 \mathrm{~A}$ ). According to the same regression equation, the grain yield of $18.58 \mathrm{~g}$ was achieved at $25.26 \mathrm{~g} \mathrm{dm}^{-3}$ of wood ash (Fig 3B).

This increase in grain yield is correlated with the increase in the other factors such as shoot and root dry mass, number and dry weight of pods, which may be explained by the potential of wood ash as a soil acidity corrective and increasing available nutrient.

Previous studies have reported increasing in soil $\mathrm{pH}$ by the application of wood ash doses (Varela et al., 2013; Sirikare et al., 2015; Pereira et al., 2016; Quesada et al., 2017). With the increase of $\mathrm{pH}$ the soil acidity is neutralized. It increases the available nutrients such as $\mathrm{Ca}, \mathrm{Mg}, \mathrm{K}$ and $\mathrm{P}$ for plants (Varela et al., 2013).

Potassium plays a fundamental role for both plant growth and grain formation as it is related to stomatal opening and closing (Taiz et al., 2015) and also to the transport of photoassimilates to grains (Usherwood, 1994). The supply of this nutrient occurs mainly due to the high $\mathrm{K}_{2} \mathrm{O}$ content 
Table 1. Leaf dry mass (g) and root dry mass (g) of peanut cultivars grown in Cerrado Oxisol.

\begin{tabular}{lll}
\hline Cultivar & Leaf dry mass & Root dry mass \\
\hline IAC 503 & $12.93 \mathrm{a}$ & $10.44 \mathrm{a}$ \\
IAC OL3 & $11.36 \mathrm{~b}$ & $7.79 \mathrm{~b}$ \\
\hline Means followed by the different letters in the same column differ each other at the 5\% level of probability by the F-test.
\end{tabular}
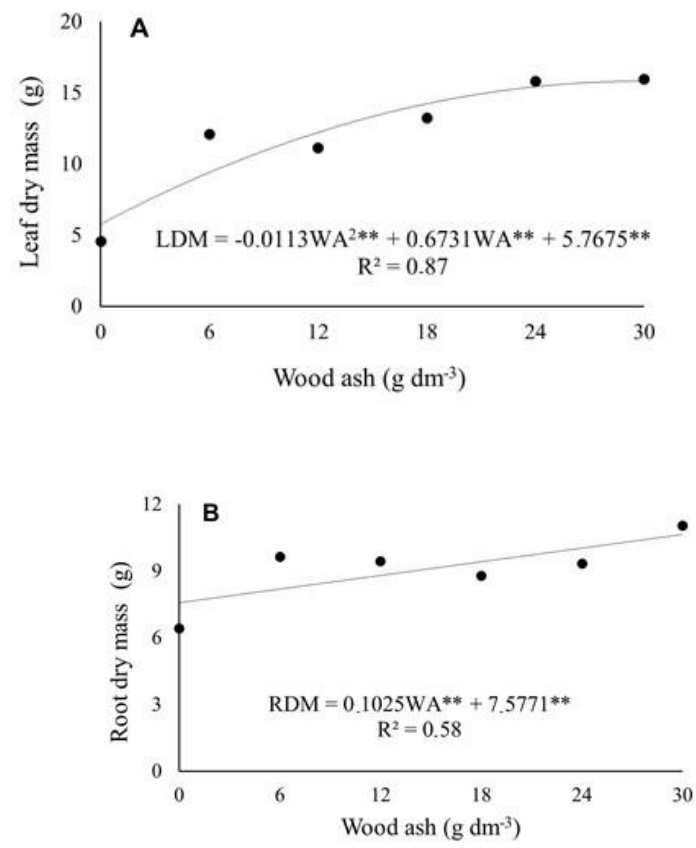

Fig 1. Leaf dry mass (A) and root dry mass (B) of peanut grown in Cerrado Oxisol fertilized with wood ash. ${ }^{* *}$ Significant at $1 \%$ level of statistical probability. LDM = Leaf dry mass; RDM = Root dry mass; WA = Wood ash dose.

Table 2. Number of pods of peanut cultivars grown in Cerrado dystrophic Oxisol.

\begin{tabular}{ll}
\hline Cultivar & Number of pods \\
\hline IAC 503 & $23.43 \mathrm{a}$ \\
IAC OL3 & $22.70 \mathrm{~b}$ \\
\hline Means followed by the different letters in the same column differ each other at the $5 \%$ level of probability by the F-test.
\end{tabular}
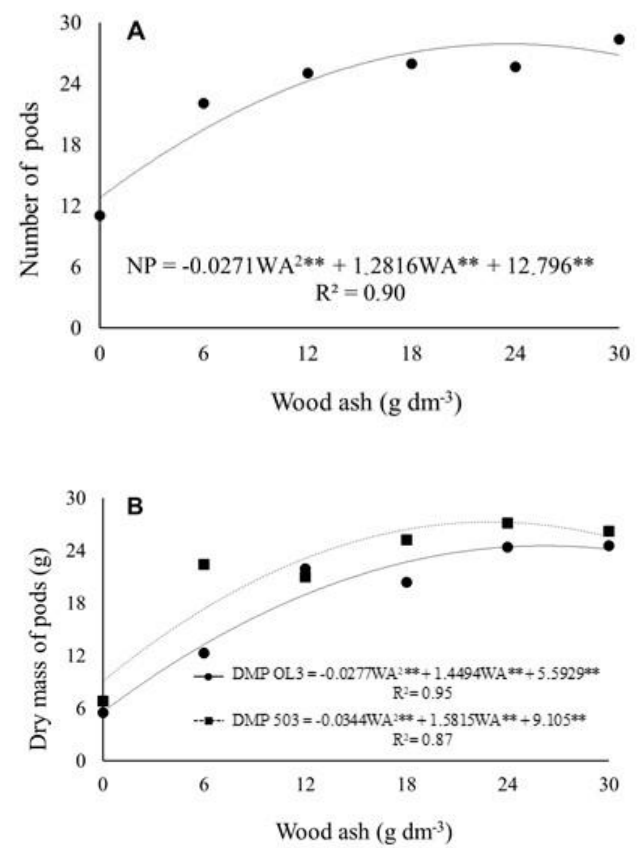

Fig 2. Number of pods (A) and dry mass of pods (g) (B) of peanut cultivars grown in Cerrado Oxisol. ${ }^{* *}$ Significant at $1 \%$ level of statistical probability. NP = Number of pods; DMP = Dry mass of pods; WA = Wood ash dose. 
Table 3. Grains pot ${ }^{-1}$ and grain yield $(\mathrm{g})$ of peanuts cultivars grown in Cerrado dystrophic Oxisol.

\begin{tabular}{lll}
\hline Cultivar & Grains pot $^{-1}$ & Grain yield \\
\hline IAC 503 & $38.13 \mathrm{a}$ & $15.34 \mathrm{a}$ \\
IAC OL3 & $36.27 \mathrm{~b}$ & $12.77 \mathrm{~b}$ \\
\hline Means followed by the different letters in the same column differ each other at the 5\% level of probability by the F-test.
\end{tabular}
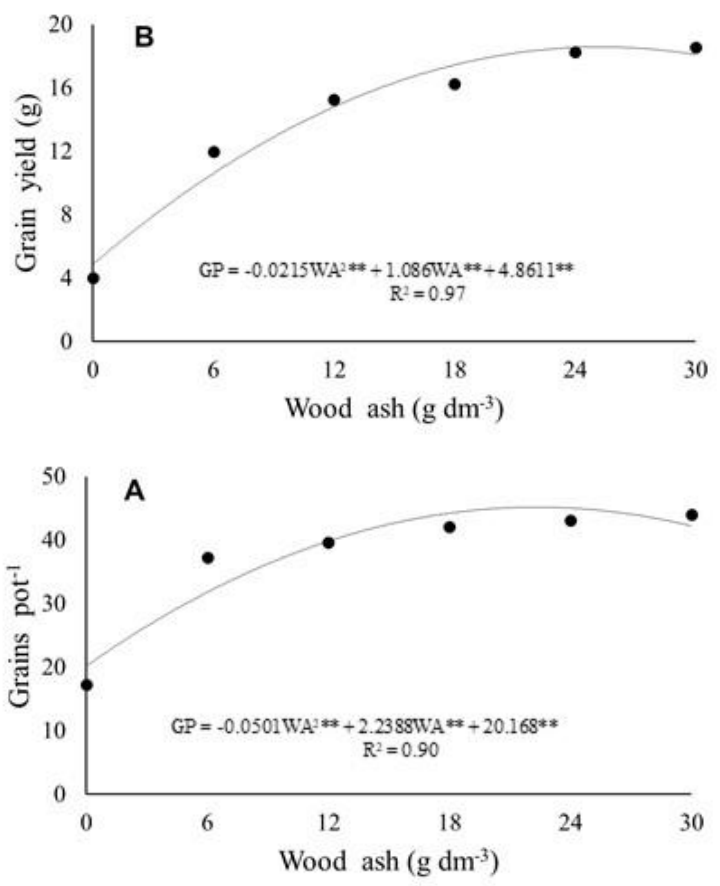

Fig 3. Grains $\operatorname{pot}^{-1}(\mathrm{~A})$ and grain yield (g) (B) of peanut fertilized with wood ash grown in Cerrado Oxisol. **Significant at $1 \%$ level of statistical probability. GP $=$ Grains pot $^{-1} ; \mathrm{GD}=$ Grain yield; $\mathrm{WA}=$ Wood ash dose.

Table 4. Chemical characteristics of the wood ash used as fertilizer and soil corrective in this experiment.

\begin{tabular}{|c|c|c|c|c|c|c|c|c|c|c|c|c|}
\hline $\begin{array}{l}\mathrm{pH} \\
\left(\mathrm{H}_{2} \mathrm{O}\right)\end{array}$ & NP* & $\mathrm{N}$ & $\begin{array}{l}\mathrm{P}_{2} \mathrm{O}_{5} \\
\text { (Total) }\end{array}$ & $\mathrm{K}_{2} \mathrm{O}$ & $\mathrm{Zn}$ & $\mathrm{Mn}$ & B & $\mathrm{Ca}$ & $\mathrm{Mg}$ & $S$ & Si & $\mathrm{Fe}$ \\
\hline & $\%$ & & --- & ------ & $\mathrm{kg}^{-1}--$ & --.-- & ב---- & & & & & \\
\hline 11.8 & 25 & 2.5 & 48.5 & 16.6 & 0.13 & 0.5 & 0.2 & 37.5 & 28.5 & 2.8 & 187 & 15.3 \\
\hline
\end{tabular}

present in the wood ash incorporated to the soil (Table 4) making the nutrient available at all stages of crop development. In a study with cowpea fertilized with sawdust ash doses, Awodun (2007) reported an increase in the amount of exchangeable $K$ in the soil and a higher $K$ concentration in the leaves, reaching $7.4 \%$ with $8 \mathrm{t} \mathrm{ha}^{-1}$ dose.

Materials and methods

\section{Plant materials}

The cultivars OL 3 and 503 were developed in Brazil by the Agronomic Institute of Campinas (IAC) and selected for this experiment because according to the institute descriptions both have runner growth habit with thick branches, high productive potential and the grains are classified with high contente of oleic acid (70 80\%) providing an extended storage capacity and higher yield when used for derivatives (IAC, 2019).

\section{Conduction of experiment}

The experiment was carried in a greenhouse at the Federal University of Mato Grosso campus of Rondonópolis, MT,
Brazil, using as substrate soil collected in native Cerrado area passed through a 4-mm sieve.

The chemical and physical properties of soil was analyzed in a sample collected at a depth of 0.0 to $0.2 \mathrm{m:} \mathrm{pH}\left(\mathrm{CaCl}_{2}\right)=$ 4.0; $\mathrm{P}=1.1 \mathrm{mg} \mathrm{dm}^{-3}$ (Mehlich $^{-1}$ ); $\mathrm{K}=43 \mathrm{mg} \mathrm{dm}^{-3} ; \mathrm{Ca}=0.5$ $\mathrm{cmol}_{\mathrm{c}} \mathrm{dm}^{-3} ; \mathrm{Mg}=0.3 \mathrm{cmol}_{\mathrm{c}} \mathrm{dm}^{-3} ; \mathrm{BS}=0.7 \mathrm{cmol}_{\mathrm{c}} \mathrm{dm}^{-3} ; \mathrm{CEC}=$ $8.3 \mathrm{cmol}_{\mathrm{c}} \mathrm{dm}^{-3} ; \mathrm{V}=9.7 \%$; O.M. $=27.1 \mathrm{~g} \mathrm{dm}^{-3}$; sand, silt and clay $=423,133$ and $444 \mathrm{~g} \mathrm{~kg}^{-1}$, respectively.

The design was a completely randomized in a $2 \times 6$ factorial arrangement with two cultivars (IAC 503 and IAC OL3) and six doses of wood ash $\left(0,6,12,18,24\right.$ and $\left.30 \mathrm{~g} \mathrm{dm}^{-3}\right)$ and five replications. The soil previously collected was homogenized with the ash doses and incubated for a period of 20 days for chemical reactions and neutralization of soil acidity. After this period, pots with a capacity of $6 \mathrm{dm}^{-3}$ were filled and sown with 10 seeds per pot with subsequent thinning keeping three plants per pot.

The wood ash used came from burning Eucalyptus sp. biomass in industrial processes, whose chemical characteristics are presented in Table 4.

The maximum soil water retention capacity was determined in laboratory by the gravimetric method (Bonfim-Silva et al., 2011). Based on the results, the irrigations were performed twice a day early morning and late afternoon so that the soil 
could maintain moisture close to $60 \%$ of maximum retention capacity.

\section{Productive characteristics analysis}

The plants were cut at the physiological maturity stage so the variables such as leaf dry mass, root dry mass, number of pods per pot, dry mass of pods, and number of grains per pot (sum of all three plants kept in pots) and grain yield were analyzed.

Dry mass were obtained using a semi-analytical balance after plant was dried in a forced air circulation at $65 \circ \mathrm{C}$ until reaching constant weight. The number of pods and grains was obtained by manual counting. Grain yield was obtained by adjusting the humidity to $13 \%$ and then weighed in semianalytical balance.

\section{Statistical analysis}

Normality teste was applied to verify if data had normal distribution. After this, data were subjected to analysis of variance at $5 \%$ probability and polynomial regression test (linear and quadratic) at up to $5 \%$ probability with SISVAR 5.3 statistical analysis software (Ferreira, 2011).

\section{Conclusions}

The fertilization with wood ash was able to increase the productive characteristics of peanuts. The cultivar IAC 503 presented higher results than the cultivar IAC OL3. The recommended range of wood ash dose for peanut productive characteristics grown in a greenhouse was between $22.34 \mathrm{~g} \mathrm{dm}^{-3}$ and $29.78 \mathrm{~g} \mathrm{dm}^{-3}$.

\section{References}

ABICAB (Associação brasileira da indústria de chocolates, amendoim e balas) (2018) Amendoim brasileiro ganha destaque no exterior. Available at:http://www.abicab.org.br/noticias/amendoimbrasileiro-ganha-destaque-no-exterior-14-05-2018/ (Accesed 07 July 2018).

Awodun MA (2007) Effect of sawdust ash on nutrient status, growth and yield of cowpea (Vigna ungiculata L. Walp). Asian J Agr Res. 1(2):92-96.

Bär CSLL, Koetz M, Bonfim-Silva EM, Silva TJA (2018) Influence of water availability and wood ash doses on the productive characteristics and water usage of potted Gerbera. J Exp Agric Int. 23(6): 1-9.

Bonfim-Silva EM, Castañon TH, Oliveira RA, Sousa HHF, Silva TJA, Fenner W (2017a) Initial development of cowpea submitted to wood ash doses. Int J Plant Soil Sc. 17(1):1-7.

Bonfim-Silva EM, Pereira MTJ, Fontenelli JV, Carvalho JMG, Schlichting AF, Silva T JA (2017b) Wood ash in Canavalia ensiformis L. cultivation on highly weathered soil in Brazil. Int J Plant Soil Sc. 16(6):1-7.

Bonfim-Silva EM, Santos TM, Dourado LGA, Silva CTR, Fenner W, Silva TJA (2018) Wood ash as a corrective and fertilizer in safflower crop in Oxisol of brazilian Cerrado. J Agric Sc. 10(9):412-422.

Bonfim-Silva EM, Silva TJA, Cabral CEA, Kroth BE, Rezende D (2011) Desenvolvimento inicial de gramíneas submetidas ao estresse hídrico. R Caatinga. 24(2):180-186.
Cabral CEA, Cabral LS, Bonfim-Silva EM, Carvalho KS, Abreu JG, Cabral, CHA (2018) Reactive natural phosphate and nitrogen fertilizers in Marandu grass fertilization. Commun Sci. 9:729-736.

Cruz-Paredes C, López-García A, Rubæk GH, Hovmand MF, Sørensen P, Kjøller R (2016) Risk assessment of replacing conventional $\mathrm{P}$ fertilizers with biomass ash: Residual effects on plant yield, nutrition, cadmium accumulation and mycorrhizal status. Sc Total Environ. 1(1):1-9.

Dall'Agnol A (2009) Plantio da soja: época e variedades. Available at: https://www.grupocultivar.com.br/ativemanager/uploads /arquivo s/artigos/gcsoja12-09.pdf (Accesed 02 March 2019).

Dindas J, Scherzer S, Mrg R, Von MK, Müller HM, Kas AR, Palme K, Dietrich P, Becker D, Bennett MJ (2018) AUX1mediated root hair auxin infux governs $\mathrm{SCF}^{\mathrm{TIR} 1 / \mathrm{AFB}}$-type $\mathrm{Ca}^{2+}$ signaling. Nat Commun. 9:1174.

EMBRAPA (Empresa Brasileira de Pesquisa Agropecuária) (2014) Sistema de Produção de Amendoim: Manejo integrado de doenças. Available at: https://www.spo.cnptia.embrapa.br/conteudo?p_p_id=co nteudoportlet_WAR_sistemasdeproducaolf6_1ga1ceportl et\&p_p_lifecycle $=0 \& p \_p \_s t a t e=$ normal $\&$ p_p_mode $=$ view \&p_p_col_id=column-

\&p_p_col_count $=1 \& p \_r \_p \_76293187$ sistemaProducaold $=3803 \& p \_r \_p \_-996514994$ topicold=3452 (Accesed 27 January 2019).

Eriksson L (1998) Dissolution of hardened wood ashes in forest soils: studies in a column experimente. Scand J For Res. 2:23-32.

Etitgni L, Campbell AG (1991) Physical and chemical characteristics of wood ash. Biol Tech. 37:173-178.

FAO (Food Agriculture Organization of United Nations) (2017) Statistics at FAO. Available at: http://www.fao.org/corp/statistics/ (Accesed 28 August 2019).

Ferreira DF (2011) Sisvar: a computer statistical analysis system. Ci Agrotec. 35(6):1039-1042.

Ferreira EPB, Fageria NK, Didonet AD (2012) Chemical properties of an Oxisol under organic management as influenced by application of sugarcane bagasse ash. $\mathrm{R} \mathrm{Ci}$ Agro. 43:228-236.

Gao C, Wang Y, Qu H (2019) Study of auxin regulation of pollen tube growth through calcium channels in Pyrus pyrifolia. Plant Growth Regul. 89:99-108.

Gong A, Shi A, Liu H, Yu H, Liu L, Lin W, Wang Q (2018) Relationship of chemical properties of different peanut varieties to peanut butter storage stability. Int Agric. 17(5): 1003-1010.

Haraldsen TK, Pedersen PA, Gronlund A (2011) Mixtures of bottom wood ash and meat and bone meal as NPK fertilizer. In: Insam H, Knapp BA (ed) Recycling of biomass ashes, 1st edn. Springer, Berlin. 3.

IAC (Instituto Agronômico de Campinas) (2017) Cultivares de amendoim - Centro de Grãos e Fibras. Available at: http://www.iac.sp.gov.br/areasdepesquisa/graos/amendo im.php (Accesed 20 January 2019).

Leyser O (2018) Auxin signaling. Plant Physiol. 176:465-479.

Marschner H (2012) Mineral nutrition of higher plants, 3rd edn. Academic Press, London. 
Nabeela F, Murad W, Khan I, Mian IA, Rehman H, Adnan M, Azizullah A (2015) Effect of wood ash application on the morphological, physiological and biochemical parameters of Brassica napus L. Plant Physiol Biochem. 95(1): 15-25.

Obernberger I, Brunner T, Bärnthaler G (2006) Chemical properties of solid biofuels - significance and impact. B Bio. 30(11):973-982.

Osaki F, Darolt MR (1991) Study of the quality of vegetal ashes for use as fertilizers in the metropolitan region of Curitiba. Agr Sci Sec J. 11(1-2):197-205.

Pereira MTJ, Silva TJA, Bonfim-Silva EM, Mazzini-Guedes RB (2016) Applying wood ash and soil moisture on gladiolus (Gladiolus grandiflorus) cultivation. Aust J Crop Sci. 10(3):393-401.

Quesada DE, Felipe-Sesé MA, López-Pérez JA, Infantesmolina A (2017) Characterization and evaluation of rice husk ash and wood ash in sustainable clay matrix bricks. Cer Int. 43:463-475.
Saarsalmi A, Smolander A, Kukkola M, Arola M (2010) Effect of wood ash and nitrogen fertlization on soil chemical properties, soil microbial processes, and stand growth in two coniferous stands in Finland. Plant Soil. 331:329-340.

Silva EB, Ferreira EA, Pereira GAM, Silva DV, Oliveira AJM (2017) Peanut plant nutrient absorption and growth. Caatinga. 30(3):653-661.

Sirikare NS, Marwa EM, Semu E, Naramabuye FX (2015) Liming and sulfur amendments improve growth and yields of maize in Rubona Ultisol and Nyamifumba Oxisol. Acta Agr Scand. 65:713-722.

Taiz L, Zeiger E, Møller IM, Murphy A (2015) Plant physiology and development, 1st edn. Sinauer Associates, Sunderland.

Usherwood NR (1994) Potassium interactions and Balanced plant nutrition. B Crop W Food. 77(1):26-27.

Varela OM, Rivera EB, Huang WJ, Chien C, Wang, YM (2013) Agronomic properties and characterization of rice husk and wood biochars and their effect on the growth of water spinach in a field test. J Soil Sci Plant Nut. 13:251-266. 